Original Research Paper

\title{
Synthesis of Feather Concentrate from Broiler Feather Waste using Different Chemical Hydrolysis Process and Effect on Its Properties
}

\author{
${ }^{1}$ Muhammad Irfan Said, ${ }^{2}$ Effendi Abustam, \\ ${ }^{3}$ Wempie Pakiding, ${ }^{4}$ Muhammad Zain Mide and ${ }^{5}$ Midiawati Sukma \\ 1,2,5 Animal Products Processing Technology Study Program, Faculty of Animal Science, Hasanuddin University, Indonesia \\ ${ }^{3}$ Animal Production Department, Faculty of Animal Science, Hasanuddin University, Indonesia \\ ${ }^{4}$ Nutrition and Animal Feed Department, Faculty of Animal Science, Hasanuddin University, Indonesia
}

Article history

Received: 05-10-2017

Revised: 02-12-2017

Accepted: 24-01-2018

Corresponding Author: Muhammad Irfan Said Animal Products Processing Technology Study Program, Faculty of Animal Science Hasanuddin University, Indonesia

Email: irfan.said@unhas.ac.id

\begin{abstract}
Feather waste, a resultant of livestock industry, has annually increased, but its existence has not been optimally utilized. Production of feather concentrate $(\mathrm{Fc})$ is regarded a beneficial application to minimze the waste. The objective of the study was to evaluate the use of $\mathrm{NaOH}$ and $\mathrm{HCl}$ as a hydrolyzing agent in Fc preparation. The results showed that microstructural changes occurred in filament molecules in keratin protein as exhibited in $T_{0}$ and $T_{1}$ treatments. Keratin molecules underwent denaturation and degradation, resulting in molecular changes of their structure. After hydrolysis reaction, in-vitro protein digestibility was increased and the highest digestibility value was achieved at $T_{1}$ treatment $(21.76 \%)$. The treatments showed no significant effects on Fc yield compared to the control, with exception of $\mathrm{T}_{3}$ treatment. Yield could indicate the preparation efficiency, in which the value seemed to decrease a result of denaturation. The relative protein content was not different from the control $\left(\mathrm{T}_{0}\right)$ especially on the $\mathrm{T}_{1}$ and $\mathrm{T}_{2}$ treatments showed no significant effects on relative protein content compared to control $\mathrm{T}_{0}$. The highest $\mathrm{pH}$ of product (9.76) was attributed to $\mathrm{T}_{1}$ treatment using $\mathrm{NaOH}$, while the lowest $\mathrm{pH}$ was found at $\mathrm{HCl}$. Different types of hydrolysis process showed significant effects $(p<0.05)$ on in-vitro digestibility of protein, yield and protein content. Application of $\mathrm{NaOH}\left(\mathrm{T}_{1}\right)$ is the best treatment compared to $\mathrm{T}_{2}, \mathrm{~T}_{3}$ and $\mathrm{T}_{0}$.
\end{abstract}

Keywords: $\mathrm{NaOH}, \mathrm{HCl}$, Hydrolysis, Concentrate, Feather, Broiler

\section{Introduction}

The production of waste generated from livestock industry has annually increased significantly. The environmentally friendly waste disposal process is a problem in today's modern world. This is due to the increasingly difficult waste dumps. Economic and environmental pressures have increased interest in the use of renewable and sustainable feed stocks, in addition to reduce dependence on non-renewable petroleum resources. Such condition encouraged the industry to find a better way to overcome the waste. The use and development of by-products of livestock have been largely carried out by researchers lately. By-product utilization, in addition to feed, has also been developed as an environmentally friendly packaging material
(Tesfaye et al., 2017; Said et al., 2016; 2011). The poultry industry produces about 6 million tons per year of feathers as a by-product. The feather was mostly composed by keratin protein, accounting for $80-90 \%$ (Mazotto et al., 2017). By the live weight of broiler chickens produced about $37 \%$ are not consumed directly by humans (Meeker and Hamilton, 2006). In 2010, approximately 25 billion $\mathrm{kg}$ of broiler and turkey meat is produced by the US (USDA, 2010).

A total of $44 \%$ of the weight of non-fat waste generated by the US sewage treatment industry comes from poultry. Of this amount, more than one-third is a feather waste. In 2008, the processing industry produced 604 million $\mathrm{kg}$ of feather meal. A total of $>90 \%$ is used domestically (Swisher, 2009). The feather meal was used as organic fertilizer (Hadas and Kautsky, 1994), 
biodiesel feedstock (Kondamudi et al., 2009) and as an additional feed for poultry (Elboushy et al., 1990), pig (Van-Heugten and Van-Kempen, 2002), ruminants (FAOUN, 2011) and fish (Arunlertaree and Moolthongnoi, 2008; Jamil et al., 2007).

One of the many livestock wastes produced by the poultry slaughtering industry is feather waste (Darah et al., 2013). Feathers are regarded as waste disposal and even though the amount is small. These wastes are often processed into valuable products such as feed and fertilizer (Veerabadran et al., 2012; Stingone and Wing, 2011). Uncontrolled waste disposal contributes to environmental damage and disease transmission (Tronina and Bube, 2008) and also potentially as a source of harmful arsenic toxins if not managed properly (Nachman et al., 2012). The poultry waste management system through the combustion process can have an impact on the environment (Nachman et al., 2005; 2008).

Feather waste needs to reduce using some beneficial applications such as feed ingredient. Protein source from chicken feather waste has remained a great challenge mainly related to its low digestibility. This characteristic is associated with presence of disulfide bonding components (S-S) in the keratin structure that compose the feather (Pruekvimolphan and Grummer, 2011). Keratin proteins are the main types of protein guided in feather wastes (Riffel and Brandelli, 2006). The utilization of feather wastes as animal feed especially ruminants has now become a consideration (Hasni et al., 2014).

Feed digestibility remarkably affected carrying capacity of feed for livestock. In form of feather concentrate $(\mathrm{Fc})$, the feather digestibility could be improved. The use of acid and base compounds is widely applied in hydrolysis process of feather to produce Fc. Therefore, researches pertaining their effectiveness need to be carried out.

The results before of the study show that Fc can be an alternative protein source in feed for both ruminant and non-ruminants (Scholljegerdes et al., 2005). This study aimed to evaluate the microstructural changes, in-vitro protein digestibility (Iv-PD), yield and protein content of Fc produced using chemical process method $(\mathrm{NaOH}$ and $\mathrm{HCl})$.

\section{Materials and Methods}

\section{Research Materials}

Broiler feather waste (BFW) was obtained from poultry slaughterhouse at Daya Village, Makassar, South Sulawesi. Other materials included distilled water, $\mathrm{NaOH} 1 \mathrm{M}$ (10 and 20\%, w/v), $\mathrm{HCl} 1 \mathrm{M}$ (10 and 20\%, $\mathrm{v} / \mathrm{v}$ ) of $\mathrm{HCl} 1 \mathrm{M}$. Supporting research equipment such as the Scanning Electron Microscope (SEM) (Tescan Vega $3 S B)$, oven (Memmert) and grinder (Kirin).

\section{Feather Hydrolysis}

Broiler feather waste $(50 \mathrm{~g})$ was washed using running water and dried using oven for $15 \mathrm{~h}$ at $60^{\circ} \mathrm{C}$. The feather was then hydrolized using different hydrolyzing agents, i.e., $\mathrm{HCl} 1 \mathrm{M}(10$ and $20 \%, \mathrm{v} / \mathrm{v})$ and $\mathrm{NaOH} 1 \mathrm{M}$ (10 and $20 \%, \mathrm{w} / \mathrm{v})$ for $4 \mathrm{~h}$ at room temperature. Hydrolized feather was washed with running water and dried using oven at $60^{\circ} \mathrm{C}$ for $24 \mathrm{~h}$. The dried sample was then milled for further analysis.

Parameters observed in this study included (1) micrustructure, (2) in-vitro protein digestibility (Iv-PD), (3) yield, (4) protein content and (5) $\mathrm{pH}$ value. The research was conducted experimentally based on completely random design (CRD) pattern undirectional for 4 treatments $\left(\mathrm{T}_{0}=\right.$ Control/without hydrolysis, $\mathrm{T}_{1}=$ $20 \%(\mathrm{w} / \mathrm{v}) \mathrm{NaOH} 1 \mathrm{M}, \mathrm{T}_{2}=20 \%(\mathrm{v} / \mathrm{v}) \mathrm{HCl} 1 \mathrm{M}, \mathrm{T}_{3}=10 \%$ $(\mathrm{w} / \mathrm{v}) \mathrm{NaOH} 1 \mathrm{M}+10 \%(\mathrm{v} / \mathrm{v}) \mathrm{HCl} 1 \mathrm{M})$ and 5 repetitions.

\section{Data Analysis}

The data obtained were evaluated using analysis of variance (ANOVA) in SPSS Version 15.0 statistical program. Significant difference between means was compared using Duncan's Multiple Range Test (DMRT) at 5\% level (Steel and Torrie, 1991). Meanwhile, microstructure data were descriptively evaluated:

- Microstructure analysis. Microstructure analysis of feather waste analyzed by Scanning Electron Microscope (SEM) (Tescan Vega 3SB)

- In-vitro protein digestibility (\%) (In-VtPD) (AOAC International, 1997); (Swaisgood and Catignani, 1991). In-VtPD can predict the digestibility of protein or by product accurately by minimizing costs. This method was imitated the digestive function of livestock (Moyano et al., 2015). In this study, Iv-PD of Fc was determined using pepsin method. Sample $(1 \mathrm{~g})$ was placed in mortar, added with pepsin acid solution (25 $\mathrm{ml}$ ) and incubated for $72 \mathrm{~h}$ at $50^{\circ} \mathrm{C}$ in shaking incubator. After incubation, sample was filtered using crucible no 2 , dried overnight at $103^{\circ} \mathrm{C}$ and heated at $520^{\circ} \mathrm{C}$ for $3 \mathrm{~h}$. In-VtPD value was calculated by following formula: In-VtPD $=100 \%-\%$ DII, where DII $(\%)=\mathrm{B}-\mathrm{C} / \mathrm{A} \times 100 \%$, DII $=$ dry ingested ingredients; $\mathrm{A}=$ sample weight, $\mathrm{B}=$ crucible weight after dried and $\mathrm{C}=$ initial crucible weight

- $\quad$ Yield (\%)._Yield was determined using previous method of (Giménez et al., 2005) with the following formula: Yield $=\mathrm{A} / \mathrm{B} \times 100 \%$, where, $\mathrm{A}=$ weight of $\mathrm{Fc}(\mathrm{g}) ; \mathrm{B}=$ weight of BFW (g)

- Proximate analysis (\%). The protein content (\%) was determined by proximate analysis method (AOAC International, 1997)

- $\quad p H$ value. The $\mathrm{pH}$ value was determined using $\mathrm{pH}$ meter (AOAC International, 1997). Sample $(0.5 \mathrm{~g})$ was dissolved in aquadest. The cathode end of the $\mathrm{pH}$ meter was dyed into the Fc solution and then the result was determined 


\section{Results and Discussion}

\section{Microstructure of Broiler Feather Waste}

The appearance of microstructural differences of the broiler feather waste before and after the chemical hydrolysis process was presented in Fig. 1.

Figure 1 shows the comparison of protein molecule bond structure in broiler feather waste before and after chemical hydrolysis process. The results showed that during the process of hydrolysis, protein was denaturated, yielding remarkable structural changes. Denaturation is the process by which proteins or nucleic acids lose their quaternary structures, tertiary structures and secondary structures. The denaturation process can occur due to exposiure to the physical treatments (pressure, radiation and heat) and chemical treatments (strong, basic acids, concentrated inorganic salts, organic solvents e.g alcohol or chloroform). Denaturation of proteins is also a consequence of cell death. The denatured protein may exhibit a variety of characteristics, ranging from conformational changes and loss of solubility to aggregation due to the role of hydrophobic groups (Samson et al., 2012; 2016). The appearance of pores in the keratin structure can be due to the dual diffusion process between keratin filaments (Ma et al., 2016).

\section{In-vitro Protein Digestibility (Iv-PD)}

Comparison of in-vitro protein digestibility (Iv-PD) of $\mathrm{Fc}$ in different chemical hydrolysis processes was presented in Fig. 2.

Statistical analysis revealed that different hydrolysis process applied showed significant effect $(p<0.01)$ on Iv-PD. In this case, $\mathrm{T}_{1}$ treatment $(20 \% \mathrm{w} / \mathrm{v} \mathrm{NaOH} 1 \mathrm{M})$ significantly improved the digestibility of $\mathrm{Fc}(21.76 \% \pm$ $\left.0.79^{\mathrm{d}}\right)$ compared with $\mathrm{T}_{0} \quad\left(10.40 \% \pm 1.05^{\mathrm{a}}\right), \quad \mathrm{T}_{2}$ $\left(13.65 \% \pm 0.30^{\mathrm{b}}\right)$ and $\mathrm{T}_{3}\left(15.39 \% \pm 0.45^{\mathrm{c}}\right)$ (Sukma, 2017). Hydrolysis using $\mathrm{NaOH}$ can improve the digestibility of chicken feather meal compared to the control.
Hydrolyzing agent $\mathrm{NaOH}$ could promote degradation of bonds on the feather component (Kim and Patterson, 2000). Said et al. (2017) found that protein content of Fc was comparable with the protein concentrate of the skin of the Bali cattle. The Fc contains a number of ccysteine amino acids which is the most dominant composition in the structure (Klemesrud et al., 2000). The use of Fc as a feed on pigs can be considered as much as $8 \%$ (VanHeughten and Van-Kempen, 2002) with a protein content of $63.46 \%$ (Keegan et al., 2004).

\section{Yield}

The yield was closely related to the efficiency of production process and provided a great effect on mass scale production. Giménez et al. (2005), that the yield is the number of products that produced a number of raw materials. Comparison of Fc yield produced by different chemical hydrolysis processes was presented in Fig. 3.

Statistical analysis exhibited that different hydrolysis processes showed significant effects $(p<0.05)$ on the yield. The results showed that no difference was observed among $\mathrm{T}_{0}, \mathrm{~T}_{1}$ and $\mathrm{T}_{2}$ treatments. Hydrolysis using a single hydrolyzing agent $(\mathrm{NaOH}$ or $\mathrm{HCl})$ did not affect the yield of $\mathrm{Fc}$ products. Additionally, $\mathrm{T}_{0}$ and $\mathrm{T}_{3}$ indicated a difference related to the value of yield (Sukma, 2017). This result is acceptable because $T_{3}$ treatment involves two types of hydrolyzing agent, leading to enhancement of the yield. Kołodziejska et al. (2007) found that the resulting yield was dependent on the process used. A larger yield indicates that the production process becomes more efficient.

\section{Protein Content}

Protein content of feed ingredient fundamentally affected the feed quality, since it was essential for increasing livestock productivity. Protein content of Fc produced from different hydrolysis processes was presented in Fig. 4.

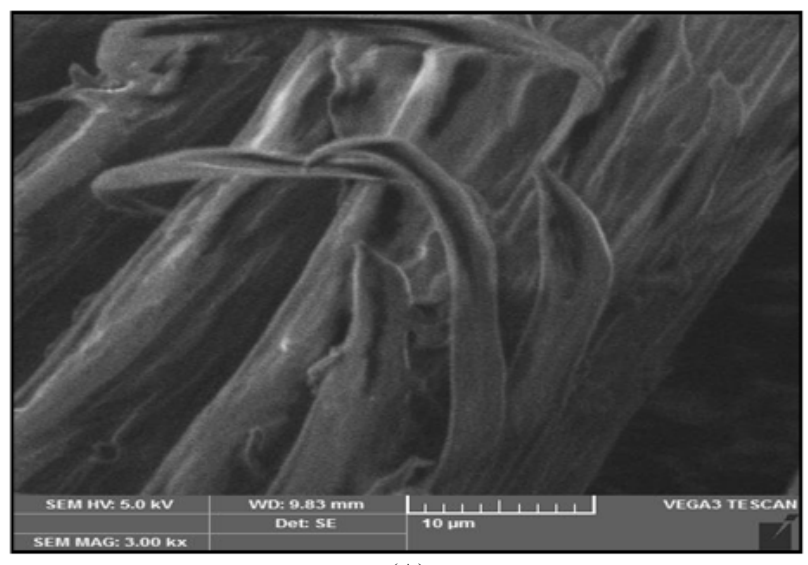

(A)

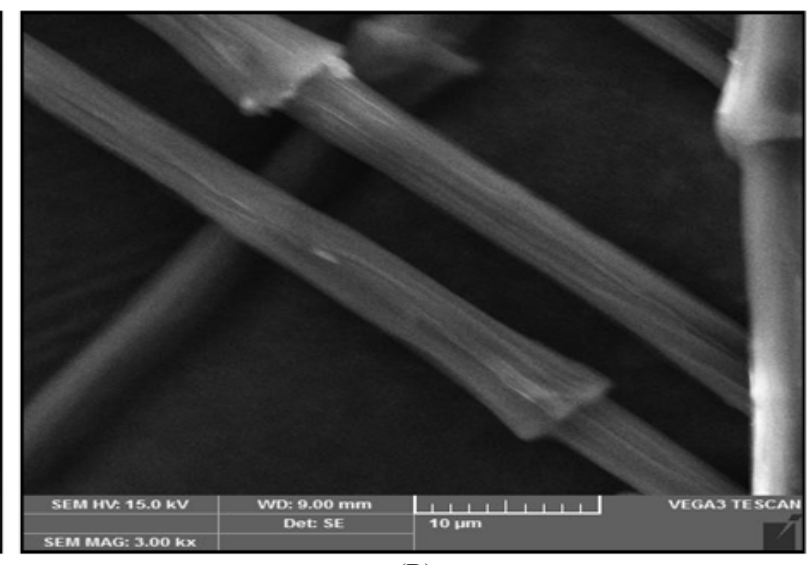

(B)

Fig. 1: Microstructural changes of broiler feather waste observed under SEM; A = Without hydrolysis (Magnification 3000× $\left(\mathrm{T}_{0}\right)$; $\mathrm{B}$ $=$ after hydrolysis $\left(\mathrm{T}_{1}\right)$ (Magnification $3000 \times$ ) 


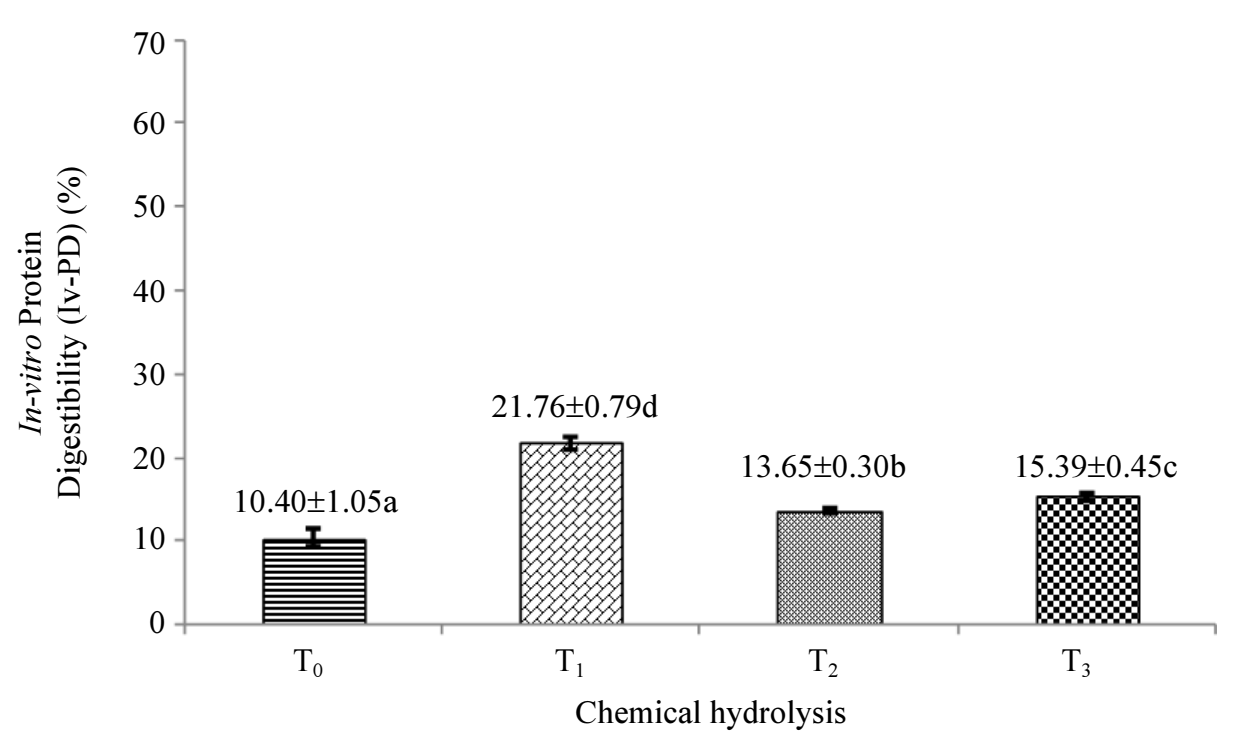

Fig. 2: Comparison of in-vitro protein digestibility (Iv-PD) (\%) of Fc in different chemical hydrolysis process. ${ }^{\text {ab,c,d }}$ Different superscripts following means showed significant differences $(p<0.05)$

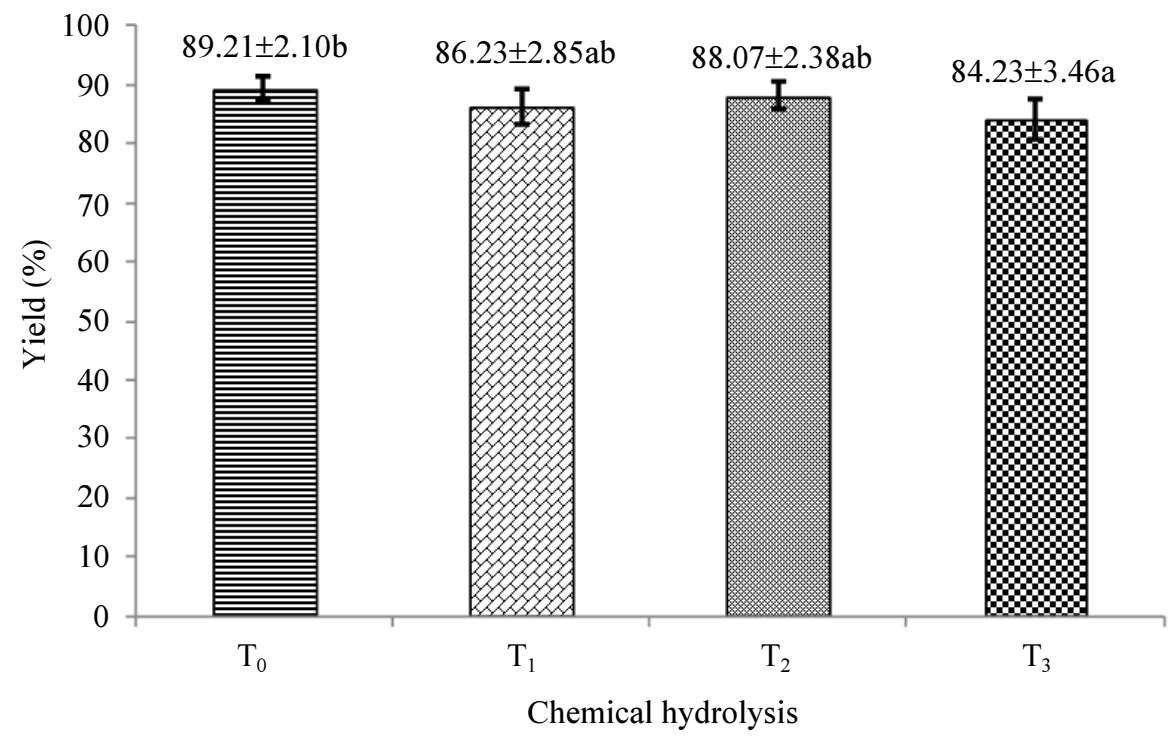

Fig. 3: Comparison of yield (\%) of Fc in different chemical hydrolysis processes. ${ }^{a, b, c, d}$ Different superscripts following means showed significant differences $(p<0.05)$

Statistical analysis showed that the use of different hydrolyzing agents significantly affected $(p<0.05)$ protein content of $\mathrm{Fc}$, ranging from 83.69-92.24\% (Sukma, 2017). We also found that $T_{0}, T_{1}$ and $T_{2}$ treatments showed no different effects on the protein content. However, $\mathrm{T}_{3}$ treatment showed the significant difference in protein levels compared to control. The combination of hydrolyzing agent significantly decreased protein levels, which might be associated with raised level of protein denaturation. Combination of acid $(\mathrm{HCl})$ and base $(\mathrm{NaOH})$ compounds allows the continued denaturation process to the protein component of Fc, thus decreasing protein content. The denaturation process can occur at temperature of $>60^{\circ} \mathrm{C}$. The denaturation process is a function of water content and temperature (Atuonwu et al., 2017) and enables to alter its biological activity. Fc produced by hydrolysis reaction has better performance in term of nutritional aspect when compared with similar feed that does not contain chicken feathers as additional ingredient.

pH Value

The $\mathrm{pH}$ value of each chemical hydrolysis process is completely different as shown in Fig. 5. 


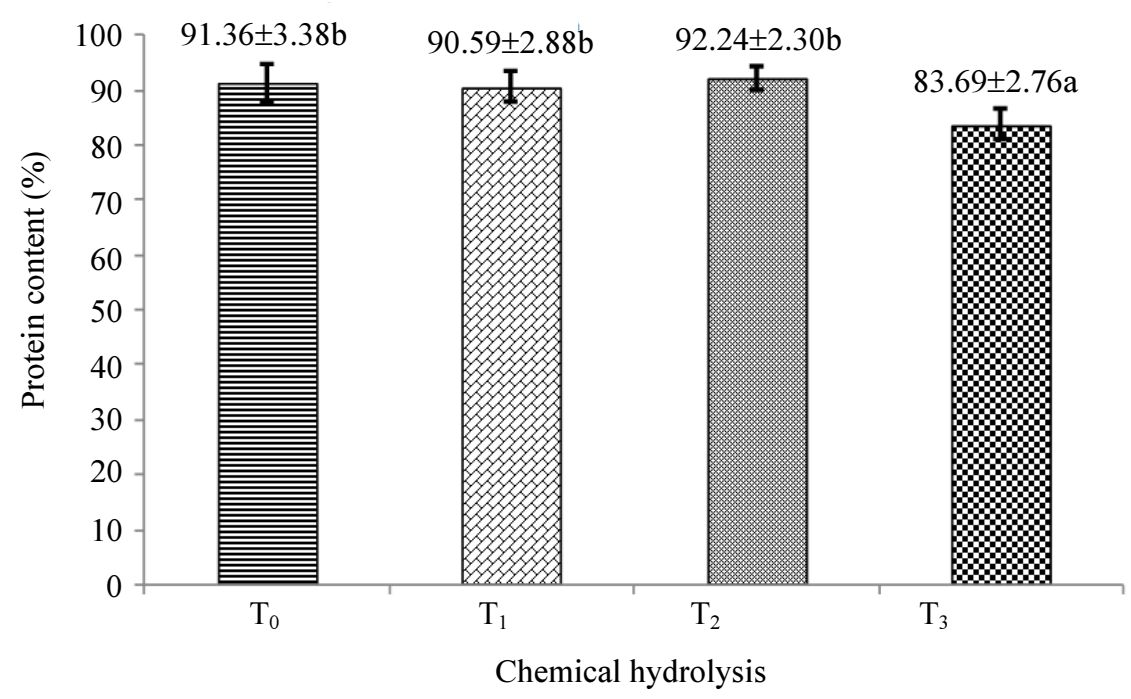

Fig. 4: Comparison of protein content (\%) of Fe in different chemical hydrolysis processes: ${ }^{\mathrm{a}, \mathrm{b}}$ Different superscripts following means showed significant differences $(p<0.05)$

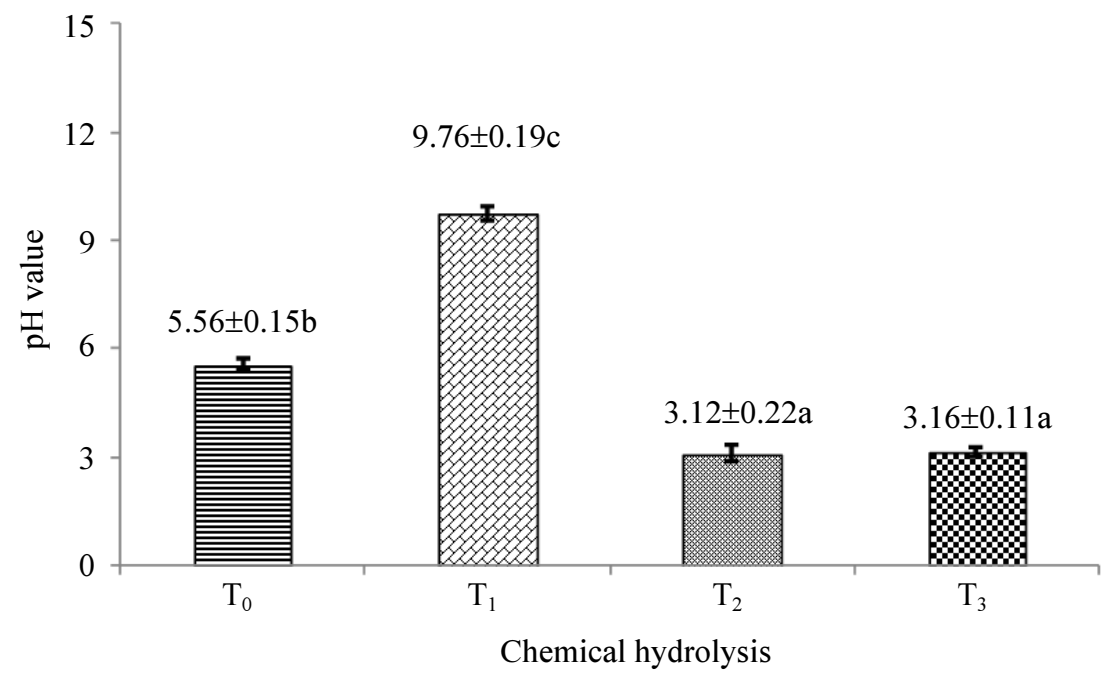

Fig. 5: Comparison of $\mathrm{pH}$ value of $\mathrm{Fc}$ in different chemical hydrolysis process: Note: ${ }^{\mathrm{a}, \mathrm{b}, \mathrm{c}}$ different superscripts showed significant differences $(p<0.05)$

Figure 5 showed that differences in chemical hydrolysis process affected $\mathrm{pH}$ value of $\mathrm{Fc}$. Treatment $\mathrm{T}_{1}$ showed the highest $\mathrm{pH}$ value compared to $\mathrm{T}_{0}, \mathrm{~T}_{2}$ and $\mathrm{T}_{3}$. This is because $\mathrm{T}_{1}$ treatment uses alkaline $\mathrm{NaOH}(\mathrm{pH}>7)$. The $\mathrm{NaOH}$ is a chemical compound having alkaline properties resulting in a higher $\mathrm{pH}$. Feather waste can be hydrolyzed at pH 5.5-7.0 (Pedersen et al., 2012).

\section{Conclusion}

In the feather microstructure, changes occur in keratin protein filament molecules. The application of hydrolysis process enhances the in-vitro protein digestibility (Iv-PD) significantly. Combination of hydrolyzing agents $\left(\mathrm{T}_{3}\right.$ treatment) decreased yield significantly compared to the control. An application of $10 \%(\mathrm{w} / \mathrm{v}) \mathrm{NaOH} 1 \mathrm{M}\left(\mathrm{T}_{1}\right.$ treatment $)$ as a hydrolysis agent resulted in the best characteristic of $\mathrm{Fc}$ in comparison with $\mathrm{T}_{2}, \mathrm{~T}_{3}$ and $\mathrm{T}_{0}$ treatments.

\section{Acknowledgment}

Authors would like to thank the Ministry of Research and Technology of Higher Education of the Republic of Indonesia, Rector of Hasanuddin University and Institute for Research and Community Service (IRCS) Hasanuddin University for research funding support through the Grants Scheme of Penelitian Unggulan Perguruan Tinggi (PUPT). 


\section{Author Contribution}

Muhammad Irfan Said: Participating in all experiments, coordinated the data-analysis and contributed to the writing of the manuscript.

Effendi Abustam: Designing the experiments and assisting data analysis.

Wempie Pakiding: Writing the manuscript and analyzing the data.

Muhammad Zain Mide: Participating in all experiments, collecting and analyzing data.

Midiawati Sukma: Collecting data and providing assistance in the writing of the manuscript.

\section{Ethics}

This article is original and has not been published or presented elsewhere. All the authors have approved the manuscript and agree with submission to this journal. There is no conflict interest to be declared.

\section{References}

AOAC International, 1997. Official Methods of Analysis of AOAC International. 18th Edn., AOAC International, Gaith-Ersburg.

Arunlertaree, C. and C. Moolthongnoi, 2008. The use of fermented feather meal for replacemnet of fish meal in the diet of oreochromis niloticus. Environ. Nat. Resour. J., 6: 13-24.

Atuonwu, J.C., J. Ray and A.G.F. Stapley, 2017. A kinetic model for whey protein denaturation at different moisture contents and temperatures. Int. Dairy J., 75: 41-50.

Darah, I., A. Nurdiyana, S. Nurulhusna, K. Jain and S. Lim, 2013. Microsporum fulvum IBRL SD3: As novel isolate for chicken feathers degradation. Applied Biochem. Biotechnol., 171: 1900-10.

Elboushy, A., A. Vanderpoel and O. Walraven, 1990. Feather meal - a biological waste - its processing and utilization as a feedstuff for poultry. Biol Wastes., 32: 39-74.

FAOUN, 2011. Feather meal, Feathermeal, Hydrolyzed feather meal, Poultry feather meal, Hydrolyzed poultry feather meal, Keratin meal. Food Agric. Organization United Nations.

Giménez, B., M.C. Gómez-Guillén and P. Montero, 2005. The role of salt washing of fish skins in chemical and rheological properties of gelatin extracted. Food Hydrocolloids., 19: 951-957.

Hadas, A and L. Kautsky, 1994. Feather meal, a semi slow-release nitrogen fertilizer for organic farming. Fert Res., 38: 165-170.

Hasni, M.S., H.A. Sahito, M.A. Memon, M.I. Sanjrani and M.A.Gopang et al., 2014. Effect of feeding various levels of feather meal as a replacement of fish meal on the growth of broiler. Int. J. Agric. Innovat. Res., 3: 505-511.
Jamil, K., G. Abbas, R. Akhtar, L. Hong and L. Zhenxing, 2007. Effects of replacing fishmeal with animal byproducts meal supplementation in diets on the growth and nutrient utilization of mangrove Red snapper. J Ocean Univ. China., 6: 292-298.

Keegan, T.P., J.M. DeRouchey, J.L. Nelssen, M.D. Tokach and R.D. Goodband et al., 2004. The effects of poultry meal source and ash level on nursery pig performance 1. J. Anim. Sci., 82: 2750-6.

Kim, W.K. and P.H. Patterson, 2000. Nutritional value of enzyme or sodium hydroxide-treated feathers from dead hens. J. Poultry Sci., 79: 528-534.

Klemesrud, M.J., T.J. Klopfenstein and A.J. Lewis, 2000. Evaluation of feather meal as a source of sulfur amino acids for growing steers. J. Anim. Sci., 78: 207-215.

Kołodziejska, I., E. Skierka, M. Sadowska, W. Kołodziejski and C. Niecikowska, 2007. Effect of extracting time and temperature on yield of gelatin from different fish offal. Food Chem., 107: 700-706.

Kondamudi, N., J. Strull, M. Misra and S.K. Mohapatra, 2009. A green process for producing biodiesel from feather meal. J. Agr. Food Chem., 57: 6163-6.

Ma, B., X. Qiao, X. Hou and Y. Yang, 2016. Pure keratin membrane and fibers from chicken feather. Int. J. Biol. Macromolecules., 89: 614-621.

Mazotto, A.M., J.L.R. Ascheri, R.L.O. Godoy, M.C.T. Damaso and S. Couri et al., 2017. Production of feather protein hydrolyzed by B. subtilis AMR and its application in a blend with cornmeal by extrusion. LWT-Food Sci. Technol., 84: 701-709.

Meeker, D. and C. Hamilton, 2006. An Overview of the Rendering Industry. In: Essentials of Rendering: All about the Animal By-Product Industry, Meeker, D.L. (Ed.), National Renderers Association, Arlington, pp: 1-16.

Moyano, F.J., M.A.S. Rodrigáñez, M. Díaz and A.G.J. Tacon, 2015. Application of in vitro digestibility methods in aquaculture: Constraints and perspectives. Rev. Aquacult., 7: 223-242.

Nachman, K.E., J.P. Graham, L.B. Price and E.K. Silbergeld, 2005. Arsenic: A roadblock to potential animal waste management solutions. Environ. Health Perspect., 113: 1123-1124.

Nachman, K.E., J.N. Mihalic, T.A. Burke and A.S. Geyh, 2008. Comparison of arsenic content in pelletized poultry house waste and biosolids fertilizer. Chemosphere., 71: 500-6.

Nachman, K.E., G. Raber, K.A. Francesconi, A. NavasAcien and D.C. Love, 2012. Arsenic species in poultry feather meal. Sci. Total Environ., 417-418: 183-188.

Pedersen, M.B., S. Yu, P. Plumstead and S. Dalsgaard, 2012. Comparison of four feed proteases for improvement of nutritive value of poultry feather meal. J. Anim. Sci., 90: 350-2. 
Pruekvimolphan, S. and R.R. Grummer, 2011. Lactation responses to sulfur-containing amino acids from feather meal or rumen-protected methionine. J. Dairy Sci., 84: 2515-2522.

Riffel, A. and A. Brandelli, 2006. Keratinolytic bacteria isolated from feather waste. Brazilian J. Microbiol., 37: 395-395.

Said, M.I., E. Abustam, W. Pakiding, M.Z. Mide and dan M. Sukma, 2017. Evaluasi penerapan $\mathrm{NaOH}$ dan $\mathrm{HCl}$ sebagai agensia penghidrolisis pada pembuatan Feather Protein Concentrate (FPC) dari limbah bulu broiler. Proceedings of the Seminar Nasional Peternakan Rakyat 3. Fakultas Peternakan Universitas Hasanuddin, Sept. 18-20, Makassar.

Said, M.I., Y. Erwanto and E. Abustam, 2016. Properties of edible film produced using combination of collagen extracts of bligon goatskin with glycerol. Am. J. Anim. Veterinary Sci., 11: 151-159.

Said, M.I., S. Triatmojo, Y. Erwanto and A Fudholi, 2011. Gelatin properties of goat skin produced by calcium hydroxide as curing material. Media Peternakan, 34: 184-189.

Samson, A.L., B. Ho, A.E. Au, S.M. Schoenwaelder and M.J. Smyth et al., 2016. Physicochemical properties that control protein aggregation. Open Biol., 6: 160098-160098. DOI: 10.1098/rsob.160098

Samson, A.L., A.S. Knaupp, M. Sashindranath, R.J. Borg and A.E. Au et al., 2012. Nucleocytoplasmic coagulation: An injury-induced aggregation event that disulfide crosslinks proteins and facilitates their removal by plasmin. Cell Reports., 2: 889-901.

Scholljegerdes, E.J., P.A. Ludden and B.W. Hess, 2005. Effect of restricted forage intake on ruminal disappearance of bromegrass hay and a blood meal, feather meal and fish meal supplement1. J. Anim. Sci., 83: 2146-50.
Steel, R.G.D. and J.H. Torrie, 1991. Principle and Procedure of Statistics. 2nd Edn., International Book Company, Tokyo.

Stingone, J.A. and S. Wing, 2011. Poultry litter incineration as a source of energy: Reviewing the potential for impacts on environmental health and justice. New Solut. J. Environ. Occup. Health Pol., 21: 27-42.

Sukma, M., 2017. Kualitas Kimia Tepung Bulu Ayam Broiler dengan Proses Perendaman dalam Larutan $\mathrm{HCl}$ dan $\mathrm{NaOH}$. Skripsi. Fakultas Peternakan Universitas Hasanuddin, Makassar.

Swaisgood, H.E. and G.L. Catignani, 1991. Protein digestibility: Methods of assessment. Adv. Food Nutrit. Res., 35: 185-236.

Swisher, K., 2009. Market report 2008: Times were good, until prices collapsed. Render Magazine.

Tesfaye, T., B. Sithole, D. Ramjugernath and V. Chunilall, 2017. Valorisation of chicken feathers: Characterisation of chemical properties. Waste Manage., 68: 626-635.

Tronina, P. and F. Bube, 2008. Production of organic fertiliser from poultry feather wastes excluding the composting process. Pol. J. Chem. Technol., 10: 33-36.

USDA, 2010. Poultry-production and value. US Department Agric.

Van-Heughten, E. and T.A. Van-Kempen, 2002. Growth performance, carcass characteristics, nutrient digestibility and fecal odorous compounds in growing-finishing pigs fed diets containing hydrolyzed feather meal. J. Anim. Sci., 80: 171-178.

Veerabadran, V., S.N. Balasundari, D.M. Devi and D.M. Kumar, 2012. Optimisation and production of proteinacious chicken feather fertiliser by proteolytic activity of Bacillus sp. MPTK 6. Indian J. Innov. Dev., 1: 193-198. 